\title{
ANALISIS BIAYA DIFERENSIAL DALAM PENGAMBILAN KEPUTUSAN MEMBELI ATAU MEMPRODUKSI SENDIRI PADA RM. MINANG PUTRA
}

\author{
Styven Farera Nainggolan ${ }^{1}$, Ventje Ilat ${ }^{2}$, Winston Pontoh $^{3}$ \\ 1,2,3 Jurusan Akuntansi, Fakultas Ekonomi dan Bisnis, Universitas Sam Ratulangi, Jl. Kampus Bahu, Manado, \\ 95115, Indonesia \\ E-mail: styvennainggolan@gmail.com
}

\begin{abstract}
In this era of globalization the economy plays an important role so that competition in the business world is increasingly rapid. In running a business, the management system must be considered carefully in terms of accounting, finance, and decision making aspects. One of them is by making decisions about buying or producing their own raw materials needed to make a product. This study aims to analyze the differential costs in making or buying decisions on their own at RM. Minang Putra. This type of research is quantitative descriptive research that is a method that analyzes the problem by describing it on existing data, in the form of production cost calculation tables to determine the comparison of chicken meat production costs that can provide a clear description or description of the differential cost analysis in buying decision making or produce their own chicken meat at RM. Minang Putra. The results of the study show that the analysis of the differential cost and opportunity cost is very beneficial for RM. Minang Putra in decision making. And a better decision was taken by the RM. Minang Putra is self-producing because the costs incurred are more efficient when compared to buying chickens from outside.
\end{abstract}

Keywords: differential costs; buying or self producing

\section{PENDAHULUAN}

Perkembangan industri makanan di Indonesia terus menunjukkan peningkatan bahkan mampu bersaing di pasar nasional. Hal ini membuat perusahaan terus mencari cara untuk dapat menghasilkan produk dengan biaya serendah mungkin dan kualitas yang tetap terjaga agar dapat meningkatkan laba perusahaan. Situasi dan kondisi perokonomian saat ini, pihak manajemen mendapat tantangan yang berat untuk mempertahankan dan mengembangkan perusahaan, apalagi untuk mencapai tujuan perusahaan yang umumnya ingin mendapat laba semaksimal mungkin sehingga pihak manajemen harus jeli dalam mengambil keputusan.

Pengambilan keputusan bukanlah hal yang mudah karena menyangkut masa mendatang yang akan dihadapi perusahaan dan sering diliputi ketidakpastian. Salah satu informasi penting untuk perencanaan dan pengambilan keputusan adalah mengenai informasi biaya diferensial. Pihak manajemen harus mengambil keputusan yang tepat dari berbagai alternatif-alternatif yang ada untuk mencapai tujuan tersebut. Pembuatan keputusan ini harus dilakukan oleh manajemen dengan dukungan berbagai informasi yang memadai agar dapat menghasilkan keputusan yang baik atas produk berkualitas dan meningkatkan laba.

Tilaar et al., (2015) menemukan bahwa secara umum usaha atau perusahaan memiliki tujuan untuk memperoleh laba yang dicapai secara periodik melalui informasi akuntansi diferensial, dimana dalam mencapai tujuan tersebut perusahaan mempunyai alat yaitu manajemen. Berhasil atau tidaknya usaha tergantung pada kemampuan manajemen dalam melaksanakan fungsi-fungsinya serta dalam melihat kemungkinan dimasa yang akan datang. Untuk itu manajemen dalam kegiatannya harus dapat merencanakan tujuan dan kegiatan dalam mencapai tujuannya tersebut. Hal ini tentunya selaras dengan fungsi pokok manajemen yaitu perencanaan (planning). Perencanaan ini penting bagi masa depan 
perusahaan, baik untuk memperoleh manfaat perlindungan (protective benefit) maupun manfaat positif (positive benefit).

Keputusan membuat atau memproduksi sendiri adalah keputusan manajemen menyangkut apakah sebuah komponen harus diproduksi sendiri ataukah dibeli dari pemasok lain. Karena berbagai macam alasan, sebuah perusahaan dapat memproduksi sebuah produk atau suatu jasa lebih murah dari pada perusahaan lain (Simamora, 2012:235). Longdong dan Tirayoh (2014) menemukan bahwa biaya diferensial adalah biaya yang berbeda dalam suatu kondisi, dibandingkan dengan kondisi-kondisi yang lain. Analisis biaya diferensial merupakan proses estimasi atau konsekuensi dari tindakan-tindakan alternatif yang dapat diambil alih oleh para pengambil keputusan. Biaya diferensial mempunyai hubungan dengan biaya peluang, dimana biaya diferensial adalah biaya yang timbul akibat adanya keputusan tertentu namun kebanyakan perusahaan masih bingung memilih alternatif mana yang lebih menguntungkan. RM. Minang Putra adalah rumah makan yang bergerak di bidang usaha kuliner, dimana dalam menjalankan aktivitas usahanya, perusahaan memerlukan bahan baku yang diperoleh dari luar perusahaan sehingga untuk kelancaran proses produksi maka perusahaan harus berusaha menyediakan sesuai dengan kebutuhan produksi. Usaha ini telah memiliki lahan sendiri, namun kendala yang dimiliki oleh pemilik usaha yakni belum mengoptimalkannya dengan baik.

\section{TINJAUAN PUSTAKA}

Riahi dan Ben Arab (2011:50) menyatakan bahwa akuntansi adalah suatu seni pencatatan, pengklasifikasian, dan pengiktisaran dalam cara yang signifikan dan satuan mata uang, transaksi-transaksi dan kejadian-kejadian yang paling tidak sebagian diantaranya, memiliki sifat keuangan, dan selanjutnya menginterpretasikan hasilnya. Baskoro (2016) menjelaskan bahwa akuntansi sebagai proses mengidentifikasi, mengukur, mencatat, mengklasifikasikan, mengikhtisarkan, dan menyampaikan informasi yang bersifat keuangan dengan tujuan membantu pengguna informasi dalam mengambil keputusan. Hery (2013:6) menyatakan bahwa akuntansi merupakan sebuah sistem informasi yang memberikan laporan kepada para pengguna informasi akuntansi atau kepada pihak-pihak yang memiliki kepentingan (stakeholders) terhadap hasil kinerja dan kondisi keuangan perusahaan. Informasi akuntansi yang dibutuhkan oleh para pengguna laporan keuangan sangat berbedabeda (bervariasi) tergantung pada jenis keputusan yang hendak diambil. Para pengguna informasi akuntansi ini dikelompokkan ke dalam dua kategori, yaitu pemakai internal (internal users) dan pemakai external (external users).

Akuntansi manajemen adalah proses pengidentifikasian, pengukuran, penghimpunan, penganalisisan, penyusunan, penafsiran, dan pengkomunikasian informasi keuangan yang digunakan oleh manajemen untuk merencanakan, dan mengendalikan kegiatan usaha di dalam sebuah organisasi, serta untuk memastikan penggunaan dan akuntabilitas sumber daya yang tepat (Simamora, 2012:13). Informasi keuangan meliputi semua informasi keuangan maupun nonkeuangan yang dibutuhkan untuk menginterpretasikan dampak peristiwa ekonomik atau konsekuensi keputusan bisnis (Simamora, 2012:12).

Blocher et al. (2010:64) menyatakan bahwa biaya akan terjadi pada saat perusahaan menggunakan sumber dayanya untuk tujuan tertentu. Koyongian et al. (2016) menyatakan bahwa akuntansi biaya adalah langkah-langkah, analisis, dan laporan informasi keuangan dan nonkeuangan yang berkaitan dengan biaya untuk memperoleh atau menggunakan sumber daya dalam suatu organisasi. Menurut Supomo (2012:103), biaya diferensial merupakan biaya yang berbeda dalam suatu kondisi, dibandingkan dengan kondisi-kondisi yang lain. Prawironegoro dan Purwanti (2018:259) memberikan pengertian biaya diferensial adalah sebagai biaya yang berbeda-beda akibat adanya tingkat produksi yang berbeda yang mengakibatkan perbedaan biaya tetap. Biaya masa yang akan datang merupakan biaya yang 
diharapkan akan terjadi dimasa mendatang dan jumlahnya harus diestimasikan pertimbangannya.

Supomo (2012:11) menyatakan bahwa informasi akuntansi diferensial merupakan informasi akuntansi yang menyajikan informasi mengenai taksiran pendapatan, biaya dan atau aktiva yang berbeda jika suatu tindakan tertentu terpilih, dibandingkan dengan alternatif tindakan lain. Menurut Tumbol et al.,(2014:27) tentang keputusan membeli atau membuat sendiri.Keputusan membeli atau membuat sendiri yang dihadapi oleh perusahaan yang sebelumnya memproduksi sendiri produknya, kemudian mempertimbangkan akan membeli produk tersebut dari pemasok luar. Sedangkan, keputusan membeli atau membuat sendiri yang dihadapi oleh perusahaan yang sebelumnya membeli produk tertentu dari pemasok luar, kemudian mempertimbangkan akan memproduksi sendiri produk tersebut.

\section{METODE PENELITIAN}

Jenis penelitian ini adalah penelitian dengan menggunakan metode deskriptif kuantitatif. Metode ini digunakan untuk menganalisis masalah dengan cara mendeskripsikannya pada data-data yang sudah ada, berupa tabel perhitungan biaya produksi untuk mengetahui perbandingan biaya produksi daging ayam yang dapat memberikan gambaran maupun uraian jelas mengenai analisis biaya diferensial dalam pengambilan keputusan membeli atau memproduksi sendiri daging ayam pada RM. Minang Putra.

Teknik analisis data yang digunakan dalam penelitian ini adalah analisis deskriptif, yaitu untuk menggambarkan berbagai karakteristik data yang berasal dari suatu sampel (Sujarweni, 2016:46). Penelitian ini mendeskripsikan dan menggambarkan data yang telah terkumpul serta menerapkannya sedemikian rupa sehingga dapat ditarik kesimpulan untuk menjawab permasalahan yang ada.

Penelitian ini juga menggunakan analisa kuantitatif yaitu informasi akuntansi diferensial untuk menghitung biaya produksi perusahaan dengan cara membandingkan biaya produksi pada saat memproduksi sendiri daging ayam tersebut dengan harga daging ayam yang ditawarkan oleh pemasok. Prosedur pengumpulan data dalam penelitian ini adalah dengan mengumpulkan data sesuai tatacara penelitian sehingga diperoleh data yang dibutuhkan dengan menggunakan teknik dokumentasi, observasi dan wawancara.

\section{HASIL PENELITIAN DAN PEMBAHASAN \\ 4.1. Hasil penelitian}

Rumah Makan (RM) Minang Putra adalah salah satu tempat makan yang sudah terkenal di daerah Manado maupun sekitarnya. RM Minang Putra ini sudah lama dibuka sejak tahun 1967 dan masih beroperasi sampai saat ini. RM Minang Putra berlokasi di Jl. Sarapung, Lawangirung, Kecamatan Wenang. Usaha rumah makan ini adalah usaha milik keluarga $\mathrm{Hj}$. Safri Z Tanjung. Awalnya RM Minang Putra ini hanya menyediakan menu daging ayam saja baik bakar maupun goreng, tetapi seiring berjalannya waktu dengan persaingan dalam dunia usaha kuliner yang semakin ketat, maka RM Minang Putra dengan kreatifitasnya menciptakan menu andalan lainnya seperti rendang, tuna, mujair dan masih banyak menu andalan. Daging ayam kampung dan sambal khas dari RM Minang Putra menjadi menu andalan yang diminati. Berdasarkan informasi yang diperoleh dari RM Minang Putra bahwa setiap harinya rumah makan ini menjual 200 ekor atau $200 \mathrm{~kg}$ daging ayam di bagi menjadi empat bagian, dua bagian paha dan dua bagian dada, dengan harga per porsinya Rp.28.000. Harga per porsi Rp.28.000 ini merupakan harga yang menjadi patokan perhitungan karena kebanyakan yang dijual ayam berukuran sedang. Tabel 1 menunjukkan biaya untuk memproduksi daging ayam berjumlah Rp. 1.326.500.000 dimana biaya-biaya produksi tersebut berupa biaya bahan baku langsung sebesar Rp. 1.241.500.000, biaya tenaga kerja langsung sebesar Rp. 72.000.000, dan biaya overhead pabrik sebesar Rp. 13.000.000. 


\begin{tabular}{|c|c|c|c|c|}
\hline Biaya Produksi & Keterangan & Jumlah Unit & Harga Unit & Total \\
\hline Bahan baku & Bibit & 72.000 Ekor & Rp. 17.000 & Rp.1.224.000.000 \\
\hline $\begin{array}{l}\text { Biaya tenaga } \\
\text { kerja langsung }\end{array}$ & Beras/Jagung & $5.000 \mathrm{Kg}$ & Rp. 3.500 & $\begin{array}{ll}\text { Rp. } & 17.500 .000 \\
\text { Rp. } & 72.000 .000\end{array}$ \\
\hline $\begin{array}{l}\text { Biaya overhead } \\
\text { pabrik }\end{array}$ & $\begin{array}{l}\text { Penyusustan } \\
\text { Peralatan } \\
\text { Biaya Listrik } \\
\text { Penyusutan } \\
\text { Mesin }\end{array}$ & & & $\begin{array}{ll}\text { Rp. } & 5.400 .000 \\
& \\
\text { Rp. } & 3.600 .000 \\
\text { Rp. } & 4.000 .000\end{array}$ \\
\hline Total & & & & Rp.1.326.500.000 \\
\hline
\end{tabular}

Sumber : Data Olah, 2019

Tabel 2 menyajikan perbandingan biaya diferensial, dimana diketahui bahwa ada beberapa biaya diferensial yang muncul saat perusahaan memilih alternatif untuk membuat sendiri yaitu, biaya bahan baku langsung, biaya tenaga kerja langsung, dan biaya overhead pabrik. Total biaya yang akan dikeluarkan oleh pihak perusahaan jika memutuskan untuk memproduksi sendiri daging ayam setiap tahunnya yaitu sejumlah Rp. 1.326.500.000. Biaya yang akan dikeluarkan oleh perusahaan jika memilih alternatif untuk membeli ikan dari luar yaitu sejumlah Rp. 2.304.000.000 sehingga terjadi penghematan biaya sebesar Rp. 977.500.000. RM Minang Putra memilih alternatif membeli dari luar karena dalam memproduksi ayam membutuhkan jangka waktu 6-7 bulan sehingga tidak memungkinkan rumah makan memproduksi daging ayam untuk kebutuhan sehari.

Tabel 2. Perbandingan biaya diferensial membeli atau membuat sendiri periode 2018

\begin{tabular}{|c|c|c|}
\hline Keterangan & Membeli dari luar & Memproduksi sendiri \\
\hline Biaya Bahan Baku Langsung & & Rp. 1.241 .500 .000 \\
\hline Biaya Tenaga Kerja & & 72.000 .000 \\
\hline Biaya Overhead Pabrik & & 13.000 .000 \\
\hline Harga Beli (72.000 Kg x Rp. 32.000) & Rp. 2.304.000.000 & \\
\hline Total Biaya Diferensial & Rp. 2.304.000.000 & \\
\hline Penghematan Biaya & & Rp. $\quad 977.500 .000$ \\
\hline
\end{tabular}

Sumber : Data Olah, 2019

Besarnya laba diferensial dinyatakan dengan rumus:

Laba Diferensial $=$ Pendapatan Diferensial - Biaya Diferensial

Pedoman untuk menentukannya ada tiga macam cara yaitu, jika alternatif keputusan mempunyai pendapatan diferensial dan biaya diferensial dan biaya diferensial yang berbeda, maka laba diferensial adalah sebesar selisih antara pendapatan diferensial dengan biaya diferensial. Jika pendapatan pada alternatif keputusan besarnya sama, maka laba diferensialnya adalah sebesar penghematan biaya antara alternatif yang satu dibandingkan dengan alternatif lainnya. Biaya pada alternatif keputusan besarnya sama, maka laba diferensial adalah sebesar pendapatan diferensialnya yaitu perbedaan antara pendapatan pada alternatif yang satu dibandingkan dengan pendapatan pada alternatif lainnya. Tabel 3 menunjukkan bahwa seluruh penjualan dengan total biaya diferensial yang didapatkan perusahaan jika membeli dari luar adalah Rp 5.760.000.000, sedangkan jika membuat sendiri sebesar Rp. 6.737.500.000, sehingga mendapatkan laba diferensial sebesar Rp. 977.500.000. Berdasarkan analisis biaya diferensial dapat diputuskan bahwa perusahaan lebih baik 
membuat sendiri karena mendapatkan selisih laba yang lebih tinggi dibandingkan membeli dari luar yaitu sebesar Rp. 977.500.000.

Tabel 3. Laporan laba/rugi membeli atau memproduksi sendiri periode 2018

\begin{tabular}{lcc}
\hline \multicolumn{1}{c}{ Keterangan } & Membeli dari luar & Memproduksi sendiri \\
\hline Penjualan & Rp. 8.064.000.000 & Rp. 8.064 .000 .000 \\
Biaya Bahan Baku Langsung & & Rp. 1.241 .500 .000 \\
Biaya Tenaga Kerja Langsung & & Rp. 72.000 .000 \\
Biaya Overhead Pabrik & Rp. 13.000 .000 \\
Harga Beli (72.000 x Rp. 32.000) & Rp. 2.304.000.000 & \\
Total Biaya Diferensial & Rp. 2.304.000.000 & Rp. 1.326 .500 .000 \\
Penjualan Biaya Diferensial & Rp. 5.760.000.000 & Rp. 6.737 .500 .000 \\
Penghematan Biaya & & Rp. 977.500 .000 \\
\hline Sumber : Data Olah, 2019 & &
\end{tabular}

\subsection{Pembahasan}

Keuntungan diartikan sebagai jumlah pendapatan dikurangi dengan jumlah pengeluaran, yakni jumlah uang yang didapat oleh sebuah usaha selama masa perhitungan tertentu. Secara umum, semakin banyak keuntungan yang didapatkan maka semakin baik, karena keuntungan dapat diinvestasikan kembali ke dalam usaha atau disimpan oleh pemilik usaha. Kemampuan untuk menentukan keuntungan dalam usaha secara akurat merupakan bagian yang penting dalam sebuah usaha, agar dapat mempertimbangkan tingkat kesehatan finansial sebuah usaha.

Hasil analisis biaya diferensial pada RM Minang Putra menyimpulkan bahwa tujuan utama rumah makan ini adalah untuk meningkatkan laba, untuk mencapai tujuan tersebut maka manajer harus bisa mengambil keputusan yang tepat guna meningkatkan laba perusahaan. Berdasarkan penelitian diatas, dari hasil perbandingan membeli atau memproduksi sendiri, keputusan memproduksi sendirilah yang lebih tepat diambil karena dapat menghemat biaya dibandingkan membeli dari luar. Laporan laba/rugi membeli atau memproduksi sendiri menunjukkan perusahaan lebih baik memproduksi sendiri karena akan mendapatkan laba diferensial yang lebih tinggi dibandingkan membeli dari luar.

Keputusan yang tepat yang dapat diambil manajemen adalah memproduksi sendiri karena mendapatkan laba diferensial yang lebih tinggi dibandingkan membeli dari luar serta dapat menghemat biaya. Hasil penelitian ini memiliki kesamaan dengan Lantu et al. (2016) yang menunjukkan bahwa pengambilan keputusan membuat sendiri lebih tepat dibandingkan membeli dari luar. Hasil penelitian ini juga memiliki hasil serupa dengan Rantung (2014) yang menunjukkan bahwa pengambilan keputusan memproduksi sendiri lebih tepat dibandingkan membeli dari luar. Penelitian ini juga serupa dengan Hidayati (2013), dan Hariawan (2014) yang menunjukkan bahwa keputusan memproduksi sendiri lebih menguntungkan karena dapat menghemat biaya.

\section{KESIMPULAN DAN SARAN}

\subsection{Kesimpulan}

Hasil penelitian ini menyimpulkan bahwa sebaiknya RM Minang Putra memilih alternatif memproduksi sendiri dari pada membeli dari luar karena dengan memproduksi daging ayam sendiri terjadi penghematan biaya yang cukup besar sebanyak Rp. 977.500.000 sehingga bisa lebih menguntungkan usaha. Selain itu, RM Minang Putra sebaiknya memproduksi sendiri daging ayam karena mendapatkan selisih laba yang tinggi dibandingkan membeli dari luar daging ayam agar supaya menguntungkan perusahaan. 
Berdasarkan hasil analisis biaya peluang yang muncul jika RM Minang Putra menyewakan lahan (kandang) maka memproduksi sendiri menduduki posisi lebih mahal sehingga pada posisi ini keputusan akan beralih menjadi membeli dari luar. Berdasarkan hasil penelitian, RM. Minang Putra memilih alternatif membeli dari luar daging ayam karena dalam memproduksi daging ayam membutuhkan jangka waktu 3 bulan sehingga tidak memungkinkan rumah makan memproduksi sendiri untuk kebutuhan sehari. Daging ayam yang diambil dilahan hanya sebatas tambahan dan jumlah pesanan daging ayam yang banyak tiap harinya jadi perusahaan memilih alternatif yang paling cepat dan gampang yaitu membeli dari luar.

\subsection{Saran}

Saran penelitian ini adalah sebaiknya RM Minang Putra memproduksi sendiri bahan baku daging ayam mengingat biaya yang dikeluarkan lebih rendah dari pada membeli dari luar karena dapat melakukan penghematan biaya dan juga lebih menguntungkan. Selain itu, dengan menyewakan lahan kandang maka RM. Minang Putra dapat melakukan penghematan biaya tenaga kerja yang dapat digunakan untuk membeli daging ayam dari luar.

\section{DAFTAR PUSTAKA}

Baskoro, A. A. (2016). Penerapan Standar Akuntansi Keuangan Entitas Tanpa Akuntabilitas Publik (SAK-ETAP) pada Serabi Notosuman Malang. Thesis. University of Muhammadiyah Malang. http://eprints.umm.ac.id/id/eprint/45192

Blocher, E. J., Stout, D. E., \& Cokins, G. (2010). Cost management: A strategic emphasis, $5^{\text {th }}$ Edition. United States: McGraw-Hill/Irwin.

Hariawan, I. (2014). Analisis biaya diferensial dan biaya peluang dalam pengambilan keputusan membeli atau memproduksi sendiri pada RM. Pondok Teterusan. Jurnal EMBA: Jurnal Riset Ekonomi, Manajemen, Bisnis dan Akuntansi, 2(4), 762770.https://ejournal.unsrat.ac.id/index.php/emba/article/view/6466

Hery, C. (2013). Teori Akuntansi. Jakarta: Lembaga Penerbit Fakultas Ekonomi Universitas Indonesia.

Hidayati, A. (2014). Analisis biaya diferensial sebagai dasar pengambilan keputusan menerima atau menolak pesanan khusus (Studi kasus pada Perusahaan Kecap Cap "Kuda" Tulungagung tahun 2013). Jurnal Administrasi Bisnis, 11(1), 1-8. http://administrasibisnis.studentjournal.ub.ac.id/index.php/jab/article/view/465

Koyongian, R., Tinangon, J. J., \& Elim, I. (2016). Analisis biaya peluang dalam pengambilan keputusan membeli atau memproduksi sendiri bahan baku olahan pada CV. Karmelindo. Jurnal EMBA: Jurnal Riset Ekonomi, Manajemen, Bisnis dan Akuntansi, 4(1),

431-440.

https://ejournal.unsrat.ac.id/index.php/emba/article/view/11610

Lantu, S. E. A., Karamoy, H., \& Tirayoh, V. Z. (2016). Analisis biaya diferensial dalam pengambilan keputusan membuat sendiri atau membeli dari luar produk bakery pada Hotel Granpuri Manado. Jurnal Berkala Ilmiah Efisiensi, 16(4), 501-508. https://ejournal.unsrat.ac.id/index.php/jbie/article/view/13632

Longdong, E., \& Tirayoh, V. Z. (2014). Analisis penggunaan informasi akuntansi diferensial dalam pengambilan keputusan manajemen menerima atau menolak pesanan khusus pada Modern Taylor. Jurnal EMBA: Jurnal Riset Ekonomi, Manajemen, Bisnis dan Akuntansi, 2(3),

$1112-$

1117.https://ejournal.unsrat.ac.id/index.php/emba/article/view/5783

Prawironegoro, D., \& Purwanti, A. (2018). Akuntansi Manajemen. Jakarta: Mitra Wacana Media 
Riahi, Y., \& Ben Arab, M. (2011). Disclosure frequency and earnings management: An analysis in the Tunisian Context. Journal of accounting and taxation, 3(3), 47-59. https://academicjournals.org/journal/JAT/article-abstract/F591011775

Simamora, H. (2012). Akuntansi manajemen, Edisi III. Riau: Star Gate Publisher.

Supomo, B. (2012). Akuntansi manajemen suatu sudut pandang. Yogyakarta: BPFE.

Rantung, D. (2014). Penerapan biaya diferensial dalam pengambilan keputusan membeli atau memproduksi sendiri pada RM. Pangsit Tompaso. Jurnal EMBA: Jurnal Riset Ekonomi, Manajemen, Bisnis dan Akuntansi, 2(3), 30-37. https://ejournal.unsrat.ac.id/index.php/emba/article/view/5067

Sujarweni, V. W. (2016). Kupas tuntas penelitian akuntansi dengan SPSS. Yogyakarta: Pustaka Baru Pers

Tilaar, H., Karamoy, H., \& Pontoh, W.(2015). Analisis biaya diferensial dalam pengambilan keputusan membeli atau memproduksi sendiri bahan baku daging ayam olahan pada UD. Adi Paslah Manado. Jurnal EMBA:Jurnal Riset Ekonomi, Manajemen, Bisnis dan Akuntansi, 3(1),

933-940. https://ejournal.unsrat.ac.id/index.php/emba/article/view/7622

Tumbol, W. J. N., Poputra, A. T., \& Runtu, T. (2014). Analisis dengan menggunakan informasi akuntansi diferensial dalam pengambilan keputusan membeli atau membuat sendiri bakso pada Bakso Pasuruan. Jurnal EMBA: Jurnal Riset Ekonomi, Manajemen, Bisnis dan Akuntansi, 2(2), 1440-1447. https://ejournal.unsrat.ac.id/index.php/emba/article/view/4810 